(RESEARCH ARTICLE)

\title{
Possible planting areas for Panax vietnamensis var. fuscidiscus toward poverty reduction in Vietnam
}

Pham Quang Tuyen 1, Nguyen Van Tuan 2, Nguyen Huy Hoang 3, Phung Dinh Trung 2, Pham Tien Dung 3, Trinh Ngoc Bon 1, Bui Thanh Tan 1, Nguyen Thanh Son ${ }^{1}$, Nguyen Quang Hung 1, Nguyen Thi Hoai Anh ${ }^{1}$, Nguyen Thi Van Anh 1, Tran Van Do 2,*

\author{
${ }^{1}$ Department of Forest Phytodiversity, Silviculture Research Institute, Vietnamese Academy of Forest Sciences, Hanoi, \\ Vietnam. \\ ${ }^{2}$ Department of Silviculture Foundation, Silviculture Research Institute, Vietnamese Academy of Forest Sciences, Hanoi, \\ Vietnam \\ ${ }^{3}$ Department of Forest Inventory and Planning, Silviculture Research Institute, Vietnamese Academy of Forest Sciences, \\ Hanoi, Vietnam.
}

Publication history: Received on 11 May 2019; revised on 20 May 2019; accepted on 24 May 2019

Article DOI: https://doi.org/10.30574/wjarr.2019.2.1.0034

\begin{abstract}
Laichau ginseng, Panax vietnamensis var. fuscidiscus, has been contributing to poverty reduction for ethnic communities in Vietnam. Therefore, identifying suitable planting areas becomes important for sustainable development. Four main conditions were selected for mapping, including elevation above sea level, air temperature, precipitation, and vegetation types. It was then classified to three levels of suitable, less-suitable, and not-suitable. Four corresponding digital maps were used to overlap and met areas were generated. The results indicated that total suitable area for planting Laichau ginseng was 17,339.3 ha, accounting for $1.9 \%$ total provincial land area, and the total less-suitable area was $22,438.1$ ha, accounting for $2.5 \%$. It is concluded that Laichau ginseng should be only planted in suitable areas. In other areas, trials must be conducted for further recommendations.
\end{abstract}

Keywords: Laichau ginseng; Mapping; Poverty reduction; Suitable areas; Sustainable development; Vegetation types

\section{Introduction}

Ginsengs are plants belonging to the genus Panax L. (Araliaceae). There are 19 ginsengs described worldwide and most of them distribute in eastern Asia [1]. Ginsengs are perennial forest herbs, which have been widely used as traditional medicines for health improvement [2-3] in Korea, China, Vietnam, and other Asian countries. The ginsenosides (triterpene glycosides), which were first found 50 years ago, are the main biologically active compounds found in ginsengs [4-5]. Many of these compounds are physiologically active and possess a broad range of medico-biological action. The physiological activity of triterpene glycosides is based on their ability to interact with the components of biological systems, primarily with sterols comprising the structure of biomembranes. Triterpene glycosides affect the liposome ionic permeability and flat bilayer lipid membranes. The rate of glycoside effect depends on quantitative and qualitative sterol level in the membrane. Triterpene glycosides as substances of exogenous origin exhibit physiological activity towards warm-blooded animals. They affect the metabolism, the functional state of the organs and the organism as a whole. Until recently, more than 150 different triterpene glycosides have been isolated from different Panax L. species [4-5], indicating the importance of ginsengs as medicinal forest herbs.

In 2003, ginseng was found, described, and named as Panax vietnamensis var. fuscidiscus K. Komatsu, S. Zhu \& S.Q. Cai. This ginseng has natural distributions in Yunnan province, China and Lai Chau province, Vietnam [6-7]. In Vietnam, it is

\footnotetext{
${ }^{*}$ Corresponding author

E-mail address: dotranvan@hotmail.com
} 
named as Laichau ginseng (Fig. 1). Laichau ginseng has been overharvested in nature for a long time, and recently it has been planted by local people in unsuitable areas (e.g., in low elevation zones, high annual precipitation areas, high air temperature areas, low vegetation cover areas). Until recently, $P$. vietnamensis, $P$. stipuleanatus, $P$. bipinnatifidus, $P$. vietnamensis var. fuscidiscus, and $P$. vietnamensis var. langbianensis were found to have natural distributions in Vietnam, and some of them have been planted successfully.
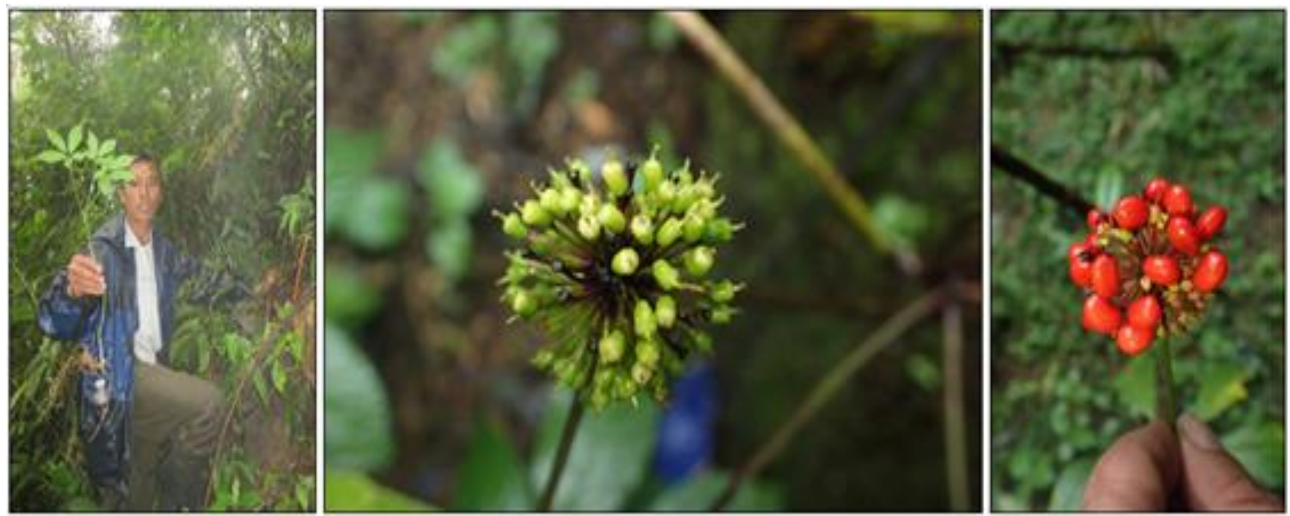

Figure 1 Full plant of Laichau ginseng (left), inflorescence with unripen green fruits (middle), and ripen red fruits (right)

Currently, the market price of Laichau ginseng rhizomes is high, ranging from 1,000 to 5,000 US\$/ $1 \mathrm{~kg}$ depending on their ages and sizes [8]. Such a high price has been attracting local people to grow Laichau ginseng for poverty reduction and economic development. To grow Laichau ginseng successfully, selecting suitable planting areas becomes important. The objective of this study is to find suitable areas for planting Panax vietnamensis var. fuscidiscus (Laichau ginseng) in Vietnam.

\section{Material and methods}

\subsection{Study site}

In Vietnam, Laichau ginseng was found only in Lai Chau province. This species was found to have natural distributions in four districts of Lai Chau province including Muong Te, Sin Ho, Phong Tho, and Tam Duong [7-8]. There is a possibility of natural distributions of Laichau ginseng in other districts of this province. Therefore, in this study, all eight districts of Lai Chau province were included for mapping areas for planting Laichau ginseng (Fig. 2).

\subsection{Gathering natural conditions}

Information on elevation above sea level, air temperature, precipitation, and vegetation types in natural distribution areas of Laichau ginseng was gathered [6-8]. These are prerequisite conditions for growing any plant; no plant can grow well in all elevation zones because of the changing of climate conditions by elevation changes. In addition, many forest herbs including ginsengs are shade-tolerant species which can only grow in the shade of others. Therefore, vegetation types were selected for mapping.

Geographical locations, where Laichau ginseng was reported to have natural distributions, were collected. It was then located on digital maps to gain information on elevation above sea level, air temperature, precipitation, and vegetation types. These conditions were classified to different categories of suitability for planting Laichau ginseng. Gathering natural information was conducted in a duration of three years (2016-2018), both from field works and published works [6-8].

\subsection{Mapping technique}

Mapping techniques use information represented in digital maps to find out the met areas. The mapping was used to identify species distribution ranges [9], plant diversity [10], and tree-potential planting sites [11].

Four digital maps were used for mapping in this work, which represent each of four main conditions; (1) topographical map for elevation, (2) precipitation map, (3) temperature map, and (4) map of vegetation types. Each main condition 
was classified to three levels including (a) "suitable”, (b) “less-suitable”, and (c) "not-suitable”. Mapping techniques were conducted as follows:

- If all four main conditions belong to "suitable", entire areas are classified as "suitable".

- If all four main conditions belong to "less-suitable", entire areas are classified as "less-suitable", and.

- If at least one of four main conditions belongs to "not-suitable", entire areas are classified as "not-suitable".

Mapping technique was conducted in a duration of one month (April 2019) using MapInfo 15.0.

\subsection{Area calculation}

After overlapping four digital maps to generate a general map (Fig. 2), there are three types of areas on the met map as suitable areas, less-suitable areas, and not-suitable areas for planting Laichau ginseng. Each area type was colored differently. Each area in a type was calculated in a unit of hectare and a sum of all areas in a type was regenerated. The areas were calculated to the district level. Therefore, each district contains suitable areas, less-suitable areas, and not-suitable areas.

\section{Results}

\subsection{Natural condition}

Laichau ginseng has natural distributions in elevation of 1,400-2,200 $\mathrm{m}$ above sea level (Table 1). The species distributes in areas with an annual temperature of $13-20^{\circ} \mathrm{C}$ and $5-7$ months of cold climate (maximum temperature $<15^{\circ} \mathrm{C}$ ), and mean annual precipitation of 1,700-2,600 mm with less than 3 dry months (monthly precipitation $<50$ $\mathrm{mm})$.

Table 1 Classifying conditions for mapping possible planting areas for Laichau ginseng

\begin{tabular}{|c|c|c|c|}
\hline \multirow[t]{2}{*}{ Main condition } & \multicolumn{3}{|l|}{ Level } \\
\hline & Suitable & Less-suitable & Not-suitable \\
\hline $\begin{array}{l}\text { Elevation above } \\
\text { level }(\mathrm{m})\end{array}$ & $1,400-2,200$ & $\begin{array}{l}1,000-1,400 \text { and } 2,200- \\
2,400\end{array}$ & $<1,000$ and $>2,400$ \\
\hline $\begin{array}{l}\text { Annual precipitation } \\
(\mathrm{mm})\end{array}$ & $1,700-2,600$ & $\begin{array}{l}1,400-1,700 \text { and } 2,600- \\
3,100\end{array}$ & $<1,400$ and $>3,100$ \\
\hline $\begin{array}{l}\text { Annual air temperature } \\
\left({ }^{\circ} \mathrm{C}\right)\end{array}$ & $13-20$ & $10-13$ and $20-22$ & $<10$ and $>22$ \\
\hline Vegetation type & $\begin{array}{l}\text { Undisturbed, nearly } \\
\text { undisturbed, and slightly } \\
\text { disturbed natural forests }\end{array}$ & $\begin{array}{l}\text { Heavily disturbed natural } \\
\text { forests, secondary forests, } \\
\text { and high standing volume } \\
\text { plantations }\end{array}$ & $\begin{array}{l}\text { Low standing volume } \\
\text { plantations, bared lands, } \\
\text { residential lands, and } \\
\text { others }\end{array}$ \\
\hline
\end{tabular}

Laichau ginseng grows in undisturbed primary or slightly disturbed evergreen broadleaved forests on sandy, shale, wet, and drained soil (Table 1). The canopy cover of the first and second layers of forest vertical structure must be $>70 \%$. Canopy height ranges from 10 to $30 \mathrm{~m}$. The vegetation layer on the forest floor is diverse and covers nearly $100 \%$ soil surface. The diverse vertical structure of forest ensures the low direct sunlight to the forest floor, microclimate conditions (low temperature and high moisture), and thick litter and humus layers on forest floors for growth of Laichau ginseng.

Laichau ginseng grows in rich organic soil. It must contain a litter layer of $>3 \mathrm{~cm}$ and humus layer underneath to maintain soil moisture wet whole year. Generally, a cloud appears at night and morning most time of year in areas where Laichau ginseng distributes naturally.

The elevation above sea level, annual temperature, annual precipitation, and vegetation types in the areas where Laichau ginseng grows naturally, were classified to three levels (Table 1). "Suitable" covers a whole range of conditions where Laichau ginseng grows naturally. Conditions were, then, extended to larger ranges to "less-suitable" and "not- 
suitable". Until recently, there was no information about the natural distribution of Laichau ginseng in the range of conditions of "less-suitable" and "not-suitable" (Table 1).

\subsection{Possible planting areas}

Total land area of Lai Chau province is 906,913 ha. Of which, 17,339.3 ha accounting for $1.9 \%$ is suitable for planting Laichau ginseng (Fig. 2; Table 2). Total less-suitable areas are 22,438.1 ha accounting for $2.5 \%$ of the total land area. Total not-suitable areas account for $95.6 \%$ land area of Lai Chau province.

Table 2 Possible planting areas (ha) for Laichau ginseng by districts

\begin{tabular}{llccc}
\hline No & District & Suitable & Less-suitable & Not-suitable \\
\hline 1 & Muong Te & $1,274.6$ & $14,823.8$ & $251,793.6$ \\
2 & Phong Tho & $3,483.7$ & $1,444.2$ & $98,373.9$ \\
3 & Sin Ho & $2,862.2$ & $1,352.1$ & $148,093.0$ \\
4 & Tam Duong & $2,797.9$ & 463.1 & $65,270.5$ \\
5 & Lai Chau City & 1.7 & 99.2 & $6,977.2$ \\
6 & Nam Nhun & $2,623.1$ & $4,120.5$ & $132,102.6$ \\
7 & Tan Uyen & $3,715.6$ & 0 & $85,993.1$ \\
8 & Than Uyen & 508.7 & 135.3 & $78,531.8$ \\
\hline Total (ha) & $17,339.3$ & $22,438.1$ & $867,135.7$ \\
Percentage of total land area (\%) & 1.9 & 2.5 & 95.6 \\
\hline
\end{tabular}

Total suitable areas in four districts (Muong Te, Phong Tho, Sin Ho, and Tam Duong), where Laichau ginseng was found to have natural distributions, are 10,418.4 ha, accounting for $1.1 \%$ total provincial land area and $62.2 \%$ of total suitable areas of Lai Chau province (Table 1 ).

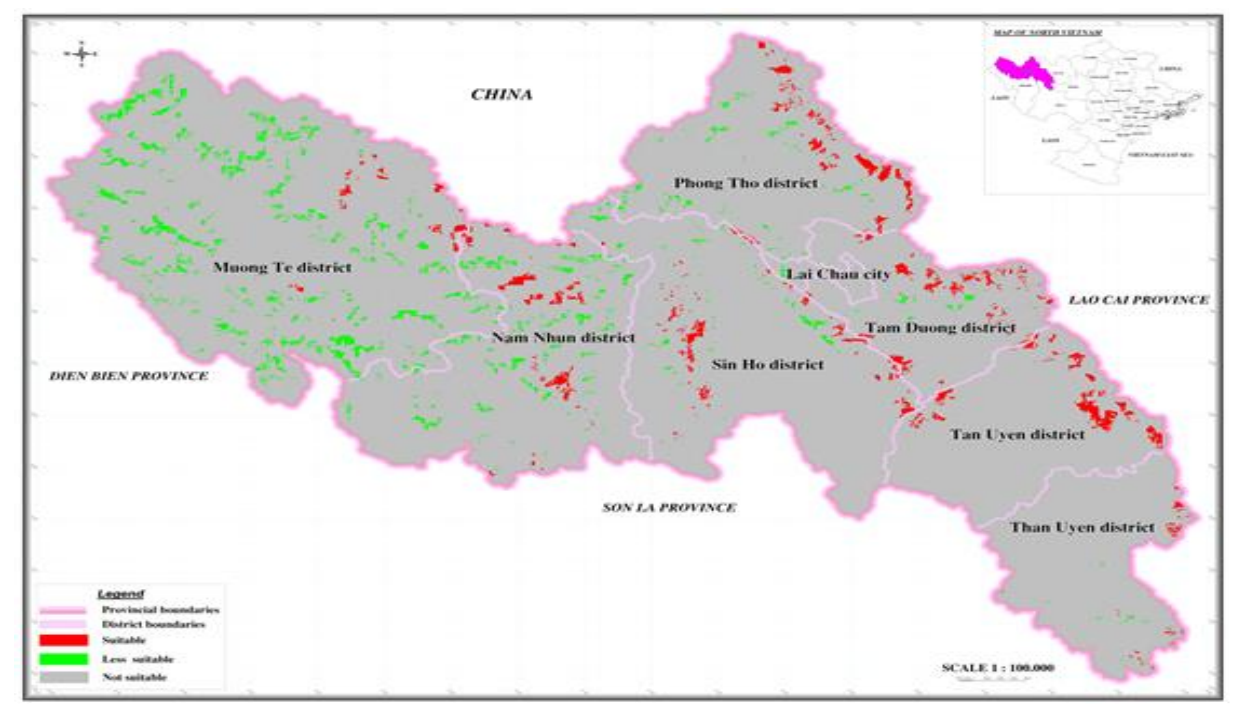

Figure 2 Map of possible areas for planting Laichau ginseng in Lai Chau province, Vietnam

Lai Chau City (1.7 ha) and Than Uyen district (507.8 ha) have low suitable area and most natural lands are not-suitable for planting Laichau ginseng (Table 1). Since they locate in central and southeast of the province in low elevation zones (Fig. 2) and with hard environment conditions of temperature and precipitation, which are known as not-suitable for Laichau ginseng. 


\section{Discussion}

Laichau ginseng is perennial forest herbs, which can only grow well in full shade of other trees and plants [2-3, 12]. Therefore, classifying vegetation of undisturbed, nearly undisturbed, and slightly disturbed natural forests is valuable [13]. Low cover of tree layer [14] will allow direct sunlight to forest floor and/or low cover of layers of shrub, bush, and seedling; and herb and other lower vegetation will also allow direct sunlight to soil surface, reducing soil moisture, litter layers, soil organic carbon etc., which is not a favorable condition for the existence of ginsengs [15].

In four main conditions selected for mapping, only vegetation could be changed by human efforts. If one grows Laichau ginseng in vegetation type with low cover, then artificial shading must be applied to the condition of similar to that of natural condition with high cover, air humidity, and soil moisture. Other three main conditions including elevation above sea level, precipitation, and air temperature are generally impossible to change. Therefore, one should not try to grow Laichau ginseng out of suitable areas (Fig. 2; Table 1). Trials should be conducted first in these areas for further practical recommendations.

Until recently, Laichau ginseng has been found to have natural distributions in four of eight districts of Lai Chau province (Fig. 2), including Muong Te, Phong Tho, Sin Ho, and Tam Duong (Table 2). However, mapping indicates that suitable areas are also available in the other four districts (Lai Chau City, Nam Nhun, Tan Uyen, and Than Uyen). This could be a good indicator that Laichau ginseng also has natural distributions in these districts. Further field investigations should be extended to areas in these districts (Fig. 2) to more understanding natural distributions of this valuable ginseng.

For practical application, Laichau ginseng should be first planted in a suitable area of four districts with natural distributions (Muong Te, Phong Tho, Sin Ho, and Tam Duong; Fig. 2). In suitable areas of the other four districts (Lai Chau City, Nam Nhun, Tan Uyen, and Than Uyen), trials should be applied first to see whether Laichau ginseng can grow there. Then further steps should be reported about the possibility of plantings. Meanwhile, Laichau ginseng should not be planted in less-suitable and not-suitable areas in any districts of the province.

\section{Conclusion}

Laichau ginseng naturally grows on the elevation of 1,400-2,200 $\mathrm{m}$ above sea level in areas with an annual temperature of $13-20^{\circ} \mathrm{C}$ and annual precipitation of 1,700-2,600 mm. The total area of 17,339.3 ha is classified as suitable areas for planting Laichau ginseng, which locate scatter in whole Lai Chau province. Local people can now grow Laichau ginseng in suitable areas for better growth and productivity with low tending requirements.

\section{Compliance with ethical standards}

\section{Acknowledgments}

This research is supported by Vietnam National Science and Technology Programme for Sustainable Development in Northwest Region Managed through Vietnam National University under grant No.KHCN-TB.16C/13-18. We would like to thank anonymous reviewers for constructive comments on the manuscript.

\section{Disclosure of conflict of interest}

Authors have declared that no competing interests exist.

\section{References}

[1] Pandey AK and Ali MA. (2012). Intraspecific variation in Panax assamicus Ban. populations based on internal transcribed spacer (ITS) sequences of nrDNA. International Journal of Biotechnology, 11, 30-38.

[2] Shim SC, Chang SK, Hur CW and Kim CK. (1987). New polyacetylene compounds from Panax ginseng C. A. Meyer. Bulletin of Korean Chemistry Society, 8, 272-275.

[3] Kochkin DM, Kachala VV, Shashkov AS, Chizhov AO, Chirva VY and Nosov AM. (2013). Malonyl-ginsenoside content of a cell-suspension culture of Panax japonicus var. repens. Phytochemistry, 93, 18-26.

[4] Qi LW, Wang CZ and Yuan CS. (2011). Ginsenosides from American ginseng: chemical and pharmacological diversity. Phytochemistry, 72, 689-699. 
[5] Yoshizaki K, Murakami M, Fujino H, Yoshida N and Yahara S. (2012). New triterpenoid saponins from fruit specimens of Panax japonicus collected in Toyama prefecture and Hokkaido (2). Chemical and Pharmaceutical Bulletin, 60, 728-735.

[6] Zhu S, Fushimi H, Qing CS, Biao CH and Komatsu K. (2003). A new variety of the genus Panax from Southern Yunnan, China and its nucleotide sequences of $18 \mathrm{~S}$ ribosomal RNA gene and matK gene. Japanese Journal of Botany, 78, 86-94.

[7] Phan KL, Le TS, Phan KL, Vo DD and Phan VT. (2013). Lai Chau ginseng Panax vietnamensis var. fuscidiscus K. Komatsu, S. Zhu \& S.Q. Cai I. morphology, ecology, distribution and conservation status. Proceeding of the 2 nd VAST-KAST Workshop on Biodiversity and Bio-active compounds, 65-73.

[8] Tuyen PQ. (2018). Growing and developing Laichau ginseng. Scientific Report. Silviculture Research Institute, Vietnamese Academy of Forest Sciences. Hanoi.

[9] Vargas JH, Consiglio T, Jorgensen PM and Croat TB. (2004). Modelling distribution patterns in a species-rich plant genus, Anthurium (Araceae), in Ecuador. Diversity Distribution, 10, 211-216.

[10] Choe H, Thorne JH and Seo C. (2016). Mapping national plant biodiversity patterns in South Korea with the MARS species distribution Model. PlosOne, 11, 0149511.

[11] Wu C, Xiao Q and McPherson EG. (2008). A method for locating potential tree-planting sites in urban areas: A case study of Los Angeles, USA. Urban Forestry and Urban Greening, 7, 65-76.

[12] Anderson RC, Fralish JS, Armstrong JE and Benjamin PK. (1993).The ecology and biology of Panax quinquefolium L. (Araliaceae) in Illinois. The American Midland Naturalist Journal, 129, 357-372.

[13] Turner IM, Tan HTW and Chua KS. (1996). Relationships between herb layer and canopy composition in a tropical rain forest successional mosaic in Singapore. Journal of Tropical Ecology, 12, 843-851.

[14] Tichy L. (2016). Field test of canopy cover estimation by hemispherical photographs taken with a smartphone. Journal of Vegetation Science, 27, 427-435.

[15] Beyfuss R. (2000). Growing ginseng fact sheet. USDA, Natural Resources Conservation Service 401.

\section{How to cite this article}

Pham QT, Nguyen VT, Nguyen HH, Phung DT, Pham TD, Trinh NB, Bui TT, Nguyen TS, Nguyen QH, Nguyen THA, Nguyen TVA and Tran VD. (2019). Possible planting areas for Panax vietnamensis var. fuscidiscus toward poverty reduction in Vietnam. World Journal of Advanced Research and Reviews, 2(1), 22-27. 